\title{
Growth Response and Gene Expression to Deficit Irrigation and Recovery of Two Perennial Ryegrass Accessions Contrasting in Drought Tolerance
}

\author{
Yiwei Jiang ${ }^{1}$ \\ College of Agronomy, Resources and Environment, Tianjin Agricultural \\ University, Tianjin, 300384, People's Republic of China; and Department of \\ Agronomy, Purdue University, West Lafayette, IN 47907
}

Yu Cui

College of Life Sciences, Shanxi Agricultural University, Taigu, Shanxi Province, 030801, People's Republic of China

\section{Zhongyong Pei, Huifen Liu, and Shoujun Sun College of Agronomy, Resources and Environment, Tianjin Agricultural University, Tianjin, 300384, People's Republic of China}

Additional index words. candidate genes, plant growth, Lolium perenne, water-use efficiency

Abstract. Perennial ryegrass (Lolium perenne) is an important cool-season forage and turfgrass species. Growth and physiological responses of perennial ryegrasses to chronic deficit irrigation (DI) and recovery following a water deficit event are not well understood. The objective of this study was to characterize plant growth, water status, and gene expression in response to DI and recovery of perennial ryegrass. Two accessions, PI598453 (drought tolerant) and PI403847 (drought susceptible), were subjected to irrigation treatments with $100 \%$ evapotranspiration (ET) replacement every other day as the control (100\% ET) and $70 \%$ ET replacement as DI treatment for 21 days in a greenhouse. After the treatment period, the DI-treated plants were shifted back to $100 \%$ ET for 7 days for recovery. The grasses were cut every 7 days, for a total of three times. Leaf relative water content (LRWC) significantly decreased at 21 days of $70 \%$ ET for both accessions, compared with the control; but to a greater extent in the more susceptible PI403847. Water-use efficiency (WUE) significantly increased 1.6-fold for PI598453 and 1.3-fold for PI403847 under $70 \%$ ET, whereas $33 \%$ reduction of leaf dry weight (LDW) was found only in PI403847. Plant height (HT) and leaf length (LL) were unaffected by $70 \%$ ET after the first two cuttings, but decreased after the third cut and did not recover to the control level for both accessions. Reductions in leaf width $(\mathrm{LW})$ under $70 \%$ ET were found at 8 and 6 days after cutting for PI598453 and for PI403847, respectively. The transcript levels of heat shock protein $(\mathrm{HSC} 70)$, iron superoxide dismutase (FeSOD), and plasma membrane intrinsic protein type 1 (PIP1) in both leaves and stems were generally downregulated during $70 \%$ ET treatment with a few exceptions but fully recovered to $100 \%$ ET after rewatering. The expression levels of cytosolic copper/zinc superoxide dismutase (cyto $\mathrm{Cu} / \mathrm{Zn} S O D$ ) and light-harvesting Chl a/b-binding proteins $(L H C B)$ did not alter under $70 \%$ ET for both accessions. Differential growth and physiological responses of perennial ryegrass accessions to DI could be used for further studying of molecular mechanisms of drought tolerance in perennial ryegrass.

Water deficit has become more of a problem for production of turf and forage grasses due to regional and localized drought stress and increasing demands for fresh water uses in other areas. Reduction in irrigation frequency or total amount of daily water supply to the plants can be a useful practice for irrigation in perennial grass production for the purpose of water conservation. DI is

Received for publication 23 Feb. 2016. Accepted for publication 29 Apr. 2016.

${ }^{1}$ Corresponding author. E-mail: yjiang@purdue. edu. a watering strategy that applies water below ET, and it has been proven to be an efficient irrigation practice in reducing water use for plants while maintaining the quality and persistence of perennial grass species. Previous studies showed that levels of DI required to maintain grass quality generally ranged from $60 \%$ to $80 \%$ ET replacement for cool-season turfgrass species (DaCosta and Huang, 2006; Fu et al., 2004, 2007; Meyer and Gibeault, 1987; Sass and Horgan, 2006), whereas DI levels varied from $40 \%$ to $80 \%$ ET in warm-season turfgrass species $(\mathrm{Fu}$ et al., 2004; Garrot and Mancino, 1994; Meyer and Gibeault, 1987). However, due to variations in temperatures and other environmental factors in the field, the practice of DI may not always produce acceptable turf and grass quality in some perennial grass species (DaCosta and Huang, 2006; Fu and Dernoeden, 2009; Turner et al., 2012).

Morphological, growth, and physiological responses of the plants to DI varied with the duration and levels of water deficit as well as species or cultivars. Infrequent irrigation resulted in a greater number of roots, longer root lengths, a larger root surface area, and higher carbohydrate levels in leaves and roots of creeping bentgrass (Agrostis stolonifera) compared with frequent irrigation (Jordan et al., 2003). Tall fescue (Schedonorus arundinaceus) subjected to $20 \%$ ET irrigation had greater total root length and surface area compared with 100\% ET (Fu et al., 2007). Creeping bentgrass subjected to DI irrigation had a lower canopy net photosynthesis and a generally similar whole plant respiration, but had greater or similar levels of watersoluble carbohydrate and total nonstructural carbohydrate in leaf, when compared with frequent-irrigated bentgrass in different years (Fu and Dernoeden, 2008). The results suggested that larger and deeper root systems and higher carbohydrate levels may promote plant drought tolerance or recovery from stress. However, DI can also cause declines in physiological activities in some grass species if the water deficit level was more severe. Turner et al. (2012) found that perennial ryegrass (L. perenne) irrigated at $33 \%$ of the requirement for optimal soil moisture levels achieved intermediate dry matter yield and maintained positive growth rates, but caused pronounced reductions in leaf dry matter, soluble carbohydrate reserves, and even the death of immature tillers. The DI-irrigated bentgrass had lower chlorophyll levels in leaf and sheath tissues, leading to unacceptable turf quality ( $\mathrm{Fu}$ and Dernoeden, 2009). Lesser accumulation of lipid peroxidation and increased activities of antioxidant enzymes were found in the drought-tolerant perennial ryegrass cultivars when subjected to DI at $30 \%$ ET for $8 \mathrm{~d}$ in growth chambers, suggesting that the tolerant cultivar can cope with water deficit through maintaining adequate antioxidant systems (Zhang et al., 2015). Collectively, responses of perennial grasses to DI may be influenced by the level and severity of DI and physiological adjustments of the plants.

At the molecular level, expression of candidate genes related to drought tolerance also varied with plant species, stress intensity, and duration. For example, the antioxidant system is an important defense mechanism in scavenging or decomposing reactive oxygen species (Bowler et al., 1992). The transcript level of $\mathrm{Cu} / \mathrm{Zn} S O D$ encoding copper/zinc superoxide dismutase can be increased, decreased, or remain stable in perennial grass species or cultivars within a species (Bian and Jiang, 2009; Jiang et al., 2010; Liu and Jiang, 2010; Xu et al., 2011; Zhang et al., 2015; Zhou et al., 2014); but overexpression of antioxidant genes often increased drought tolerance in 


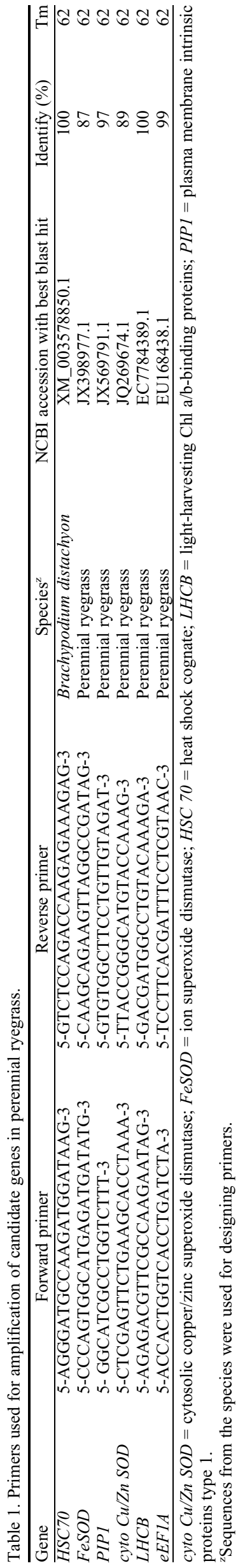

different plant species (Eltayeb et al., 2007; Prashanth et al., 2008; Van Breusegem et al., 1999; Wang et al., 2005). Other candidate genes such as aquaporins plasma membrane intrinsic proteins (PIPs) facilitating water movement and solutes across membranes may play a role in drought tolerance. Expression of PIPI in Galega orientalis was induced by salt and drought (Li et al., 2015), but the unchanged expression of $P I P 1$ genes was also observed in perennial grass species of Prairie junegrass (Koeleria macrantha) under drought stress (Jiang et al., 2010). Overexpression of OsPIP1 conferred drought tolerance by maintaining normal leaf rigidness and proper water status as well as increasing root growth under drought stress (Lian et al., 2004; Xu et al., 2014). However, the heterologous expression of TaTIP2;2 in Arabidopsis thaliana compromised its drought and salinity tolerance, suggesting that TaTIP2;2 may be a negative regulator of abiotic stress (Xu et al., 2013). The results indicate that the regulatory patterns of the PIP gene family vary with specific plant species and cultivars. Overall, the stronger expression of stress related genes could be critically important for plant adaptation to drought stress in perennial grass species.

Perennial ryegrass is one of the most economically and environmentally important cool-season grass species. It is extensively used as a turf and forage grass around the world. However, this species is generally susceptible to drought stress and needs relatively large amounts of water to sustain

Table 2. Analyses of variances for leaf relative water content (LRWC), stem relative water content (SRWC), leaf dry weight (LDW), and water-use efficiency (WUE) in perennial ryegrass under deficit irrigation.

\begin{tabular}{lcccc}
\hline Sources & LRWC & SRWC & LDW $^{z}$ & WUE $^{\mathrm{y}}$ \\
\hline Treatment (T) & $* * *$ & $* * *$ & $*$ & $* * *$ \\
Accession (A) & $* * *$ & $* * *$ & $* *$ & NS \\
Date (D) & $* * *$ & $* * *$ & - & - \\
$\mathrm{T} \times \mathrm{A}$ & $* * *$ & $*$ & $*$ & $\mathrm{NS}$ \\
$\mathrm{T} \times \mathrm{D}$ & $* * *$ & $* * *$ & - & - \\
$\mathrm{A} \times \mathrm{D}$ & $* * *$ & $* * *$ & - & - \\
$\mathrm{T} \times \mathrm{A} \times \mathrm{D}$ & $* * *$ & $* * *$ & - & - \\
\hline
\end{tabular}
ss $, *, * *, * * *$ Nonsignificant or significant at $P<$ $0.05,0.01$, and 0.001 , respectively.

${ }^{2, y}$ Data were only collected at the end of the experiment. growth. Nevertheless, our previous study identified a large variation of drought tolerance in a global collection of perennial ryegrass germplasm (Yu et al., 2013). The practice of DI could be an effective way to reduce water use while maintaining grass quality, but growth, physiological, and molecular changes of grasses in response to DI are not well understood. Particularly, how regrowth of the whole plant and individual leaves after each clipping event is affected by DI as well as recovery after DI are not known. In addition, the expression of candidate genes related to drought tolerance has not been extensively examined in perennial grasses exposed to DI. Most previous studies on gene expression of perennial grasses were conducted by using plants exposed to a constant drought stress with water withheld during the treatment (Bian and Jiang, 2009; Jiang et al., 2010; Liu and Jiang, 2010; Xu et al., 2011; Zhou et al., 2014). Therefore, this experiment was designed to characterize plant growth, water status, and gene expression in response to DI and recovery of perennial ryegrass. Exploring differential growth and physiological responses of perennial ryegrass to DI provide a basis for further exploring genetic variation and studying molecular mechanisms of drought tolerance in perennial ryegrass and other coolseason perennial grasses.

\section{Materials and Methods}

Plant materials and growth conditions. PI598453 (wild, Romania) and PI403847 (cultivated, Canada) perennial ryegrasses were chosen for this study. These two accessions have similar growth habits and texture but differed in drought tolerance (Yu et al., 2013). On 1 July 2013, seeds of each accession were planted in pots $(9 \mathrm{~cm}$ deep and $10 \mathrm{~cm}$ in diameter) containing topsoil in a plant growth chamber at Purdue University in West Lafayette, IN. Twenty days after germination, a single plant was kept in each pot and pots were then moved to a greenhouse. On 11 Nov. 2013, plants were propagated into bigger pots $(14.5 \mathrm{~cm}$ deep and $15 \mathrm{~cm}$ in diameter) and each pot had the same number of tillers and volume of soil. Plants were watered every $2 \mathrm{~d}$ and fertilized once a week

Table 3. Analyses of variances for plant height (HT), leaf length (LL), and leaf width (LW) in perennial ryegrass under deficit irrigation.

\begin{tabular}{|c|c|c|c|c|c|c|c|c|c|}
\hline Cut & Sources & HT & LL & LW & Cut & Sources & HT & LL & LW \\
\hline \multirow[t]{7}{*}{1} & Treatment (T) & $* * *$ & NS & NS & 3 & $\mathrm{~T}$ & $* * *$ & $* * *$ & $* * *$ \\
\hline & Accession (A) & $* * *$ & NS & $* * *$ & & A & $* *$ & NS & $* * *$ \\
\hline & Date (D) & $* * *$ & $*$ & $* * *$ & & $\mathrm{D}$ & $* * *$ & $* * *$ & NS \\
\hline & $\mathrm{T} \times \mathrm{A}$ & NS & NS & NS & & $\mathrm{T} \times \mathrm{A}$ & NS & NS & NS \\
\hline & $\mathrm{T} \times \mathrm{D}$ & NS & NS & NS & & $\mathrm{T} \times \mathrm{D}$ & $* * *$ & NS & NS \\
\hline & $A \times D$ & NS & NS & NS & & $\mathrm{A} \times \mathrm{D}$ & NS & NS & NS \\
\hline & $\mathrm{T} \times \mathrm{A} \times \mathrm{D}$ & NS & NS & NS & & $\mathrm{T} \times \mathrm{A} \times \mathrm{D}$ & NS & NS & NS \\
\hline \multirow[t]{7}{*}{2} & $\mathrm{~T}$ & $* * *$ & NS & NS & $\mathrm{R}$ & $\mathrm{T}$ & $* * *$ & $* * *$ & NS \\
\hline & A & $* * *$ & $*$ & $* * *$ & & A & $* * *$ & NS & NS \\
\hline & $\mathrm{D}$ & $* * *$ & $* * *$ & $* *$ & & $\mathrm{D}$ & $* * *$ & $* * *$ & NS \\
\hline & $\mathrm{T} \times \mathrm{A}$ & NS & NS & NS & & $\mathrm{T} \times \mathrm{A}$ & NS & NS & NS \\
\hline & $\mathrm{T} \times \mathrm{D}$ & $*$ & NS & NS & & $\mathrm{T} \times \mathrm{D}$ & $* * *$ & NS & NS \\
\hline & $A \times D$ & $*$ & NS & NS & & $\mathrm{A} \times \mathrm{D}$ & $* *$ & NS & NS \\
\hline & $\mathrm{T} \times \mathrm{A} \times \mathrm{D}$ & NS & NS & NS & & $\mathrm{T} \times \mathrm{A} \times \mathrm{D}$ & NS & NS & NS \\
\hline
\end{tabular}

Ns, $*, * *, * * *$ Nonsignificant or significant at $P<0.05,0.01$, and 0.001 , respectively. 
with a soluble fertilizer $(24 \mathrm{~N}-8 \mathrm{P}-16 \mathrm{~K})$ (The Scotts Company, Marysville, $\mathrm{OH}$ ) and micronutrients and were cut once a week to the height of $7-8 \mathrm{~cm}$. During the growth period, the average air temperatures were $23^{\circ} \mathrm{C}$ day/ $18{ }^{\circ} \mathrm{C}$ night and average daily photosynthetically active radiation $(P A R)$ intensity was $\approx 380 \mu \mathrm{mol} \cdot \mathrm{m}^{-2} \cdot \mathrm{s}^{-1}$ in the greenhouse.

DI treatment. The experimental treatments were started on 1 Feb. 2014. Grasses were subjected to two irrigation treatments with $100 \%$ ET replacement every other day as the control $(100 \%$ ET) and $70 \%$ ET replacement $(70 \%$ ET) as the DI treatment. Each pot was weighed every other day. The ET was calculated by water loss, determined by weighing each pot and comparing the pot weight to the value of the previous weight. The amount of water applied for the irrigation treatment was based on the calculations of $100 \%$ ET and $70 \%$ ET. Irrigation treatments were ended when the plants showed moderate to severe wilting. The total amount of water added to the pots was recorded. The DI-treated plants were then allowed to recover by adding water back to $100 \%$ ET. During the treatments, plants were fertilized and cut once a week as described above. The average day air temperatures were $23{ }^{\circ} \mathrm{C}$ day $/ 18^{\circ} \mathrm{C}$ night and the average $P A R$ was $\approx 450 \mu \mathrm{mol} \cdot \mathrm{m}^{-2} \cdot \mathrm{s}^{-1}$ with a 10 -h light period of both natural and artificial light.

Whole plant measurements. HT was measured every $7 \mathrm{~d}$ from the soil surface to the top of the uppermost leaf blade, regardless of cutting events. LW was measured at the widest point of the most mature leaf. LRWC and stem relative water content (SRWC) were determined according to the following equation: $\mathrm{RWC}=(\mathrm{FW}-\mathrm{DW}) /(\mathrm{SW}-\mathrm{DW}) \times$ $100 \%$, where $\mathrm{FW}$ is leaf or stem fresh weight, DW is the dry weight of leaf or stem after drying at $85^{\circ} \mathrm{C}$ for $3 \mathrm{~d}$, and $\mathrm{SW}$ is the turgid weight of leaf and stem after soaking in water for $4 \mathrm{~h}$ at room temperature $\left(20^{\circ} \mathrm{C}\right)$. Individual tillers were labeled for measuring LL and LW during the treatments. Clippings after each cut were collected and total DW was determined by the sum of all clippings. WUE was calculated by dividing total DW by total amount of water added.

Gene expression. The levels of transcript abundance were determined using a reverse transcriptase polymerase chain reaction. Total RNA from the grass leaves or stems was isolated using TRI Reagent (Molecular Research Center, Cincinnati, $\mathrm{OH}$ ) and was treated with DNase (TURBO DNA-free Kit; Ambion Inc., Carlsbad, CA) to remove contaminating genomic DNA. RNA $(1.0 \mu \mathrm{g})$ was reverse transcribed with the iScript cDNA synthesis kit (Bio-Rad, Hercules, CA). The amplification profile was one cycle at $95^{\circ} \mathrm{C}$ for 4 min, followed by $25-28$ cycles of $95^{\circ} \mathrm{C}$ for $30 \mathrm{~s}, 53{ }^{\circ} \mathrm{C}$ for $30 \mathrm{~s}, 72{ }^{\circ} \mathrm{C}$ for $40 \mathrm{~s}$, respectively, and a final extension step at $72{ }^{\circ} \mathrm{C}$ for $5 \mathrm{~min}$. The gene sequences of $\mathrm{HSC70}, \mathrm{FeSOD}$, $P I P 1$, cyto $C u / Z n S O D$, and $L H C B$ were used to design primers for detecting gene expression. Elongation factor $e E F 1 A$ was used for internal loading control. The detailed information for the primers used in the study was listed in Table 1.
The PCR products were resolved by $1.0 \%$ agarose gel. The bands were determined with the Doc-it gel image system (UVP, LLC, Upland, CA).

Experimental design and statistical analyses. The experiment was a randomized complete block design in a 2 (irrigation) by 2 (accession) factorial arrangement with four replicates (four pots). Irrigation and accessions
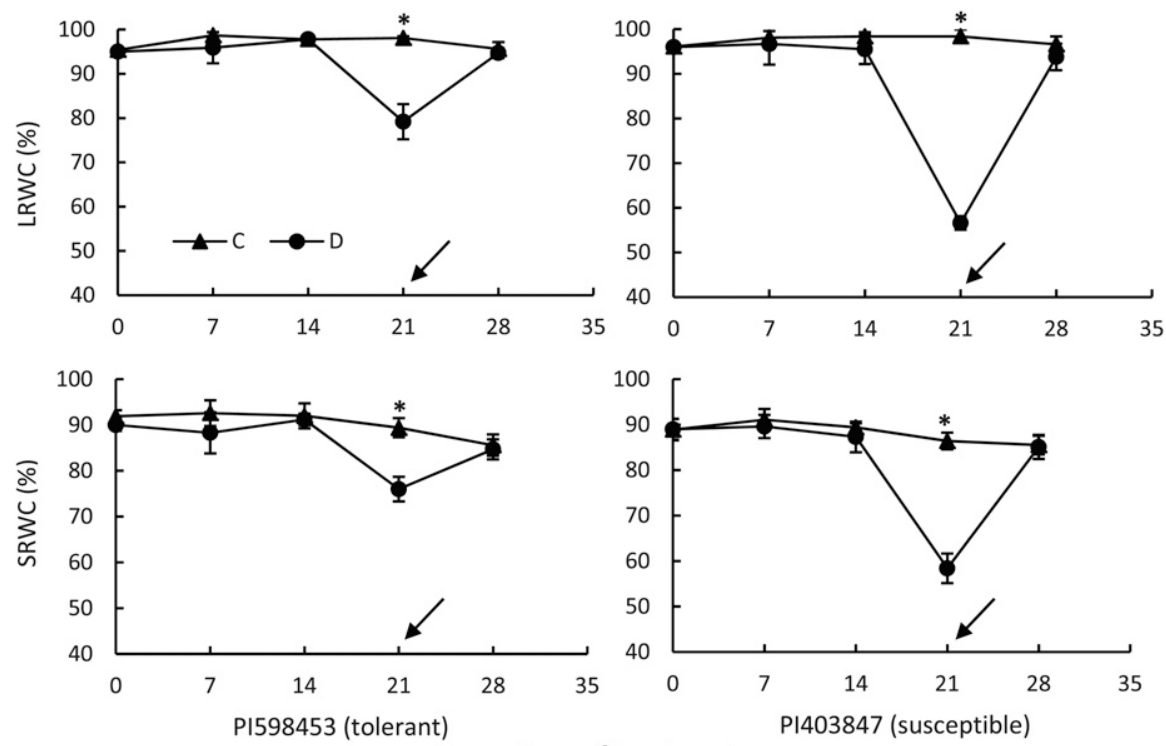

Days of treatment

Fig. 1. Leaf relative water content (LRWC) and stem relative water content (SRWC) as affected by irrigation at $100 \%$ evapotranspiration (ET) replacement as the control (C) and $70 \%$ ET replacement (D) for contrasting drought tolerant perennial ryegrass accessions. Arrow indicates recovery after rewatering. *Differences between the treatments for a given date are significant at $P<0.05$.
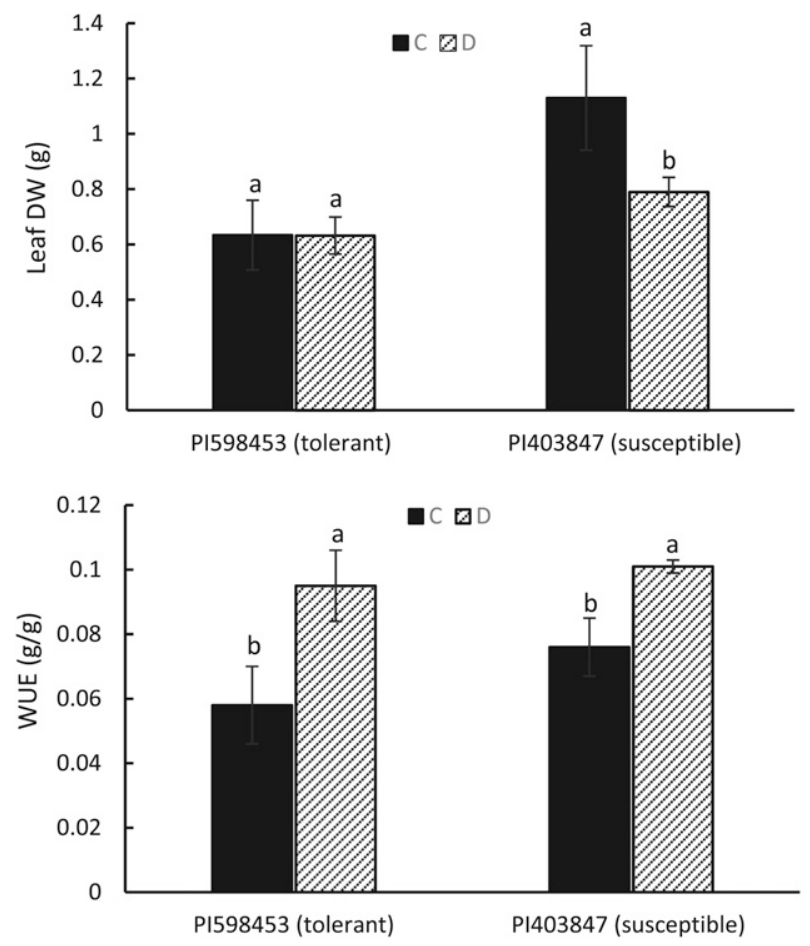

Fig. 2. Water-use efficiency (WUE) and leaf dry weight (DW) as affected by irrigation at $100 \%$ evapotranspiration (ET) replacement as the control (C) and 70\% ET replacement (D) for contrasting drought tolerant perennial ryegrass accessions. Means followed by the same letter within treatments for a given accession are not significantly different at $P<0.05$. 


\section{Results and Discussion}

Analysis of variance. Analysis of variance (ANOVA) indicated that treatment, accession, and date all had effects on LRWC and SRWC, and significant treatment $\times$ accession $\times$ date interactions were found for these traits (Table 2). Significant effects of treatment on LDW and WUE were found but accession only had effects on LDW (Table 2). Effects of treatment, accession, or date on HT were shown at all cutting events, but effects of treatment, accession, or date on LL and LW varied with different cuttings (Table 3 ). A few interactions between treatment and date or between accession and date were noted, but there were no treatment $\times$ accession $\times$ date interactions for HT, LL, and LW at each cutting event (Table 3 ).

Leaf water status. LRWC and SRWC did not change at 7 and $14 \mathrm{~d}$ of $70 \% \mathrm{ET}$, but significantly decreased after $21 \mathrm{~d}$, compared with the control for both accessions (Fig. 1). Specifically, LRWC dropped to $79.2 \%$ and $56.6 \%$ and SRWC dropped to $76 \%$ and $58.4 \%$ for PI598453 and PI403847, respectively. Both LRWC and SRWC increased back to the control level after $7 \mathrm{~d}$ of rewatering. Leaf water content has been used to screen drought-tolerant plant material and characterize drought tolerance at the whole plant level in grass species (Luo et al., 2011; Matin et al., 1989; Yu et al., 2013). The great reductions in LRWC and SRWC in PI403847 could negatively influence plant growth and physiology to water-deficit condition than that of PI598453.

LDW was unaffected by $70 \%$ ET at $21 \mathrm{~d}$ in PI598453 but was reduced by $30.4 \%$ in PI403847 (Fig. 2). Under 100\% ET, WUE was $0.058 \mathrm{~g} \cdot \mathrm{g}^{-1}$ for PI598453 and $0.076 \mathrm{~g} \cdot \mathrm{g}^{-1}$ for PI403847, but increased to $0.095 \mathrm{~g} \cdot \mathrm{g}^{-1}$ for PI 598453 and $0.101 \mathrm{~g} \cdot \mathrm{g}^{-1}$ for PI 403847 under $70 \%$ ET (Fig. 2). A drought-tolerant plant may be more capable of controlling water loss through better WUE, thus enhancing drought tolerance. Higher WUE during drydown was associated with less leaf firing and wilting tendency in kentucky bluegrass (Poa pratensis), but the WUE measured as clipping yield-to-water loss ratio may not always be a reliable predictor of turf performance under drought (Ebdon and Kopp, 2004). In a field study of three bentgrass species, irrigating at either $60 \%$ ET or $80 \%$ ET had no significant effect on WUE compared with $100 \% \mathrm{ET}$; however, differences in WUE were found among three species during the summer treatment period (DaCosta and Huang, 2006). In their study, the WUE was quantified by the ratio of canopy net photosynthetic rate to transpiration rate and carbon isotope discrimination. These results demonstrated that water use characteristics varied with species, irrigation regime, and climatic conditions as well as WUE definition.

HT was unaffected by $70 \%$ ET after the first and second cuts for both accessions, compared with $100 \%$ ET (Fig. 3). However, HT was significantly reduced by $70 \%$ ET beginning at $6 \mathrm{~d}$ for PI598453 and $4 \mathrm{~d}$ for
PI403847 after the third cut. Specifically after the third cut, HT significantly decreased from 13.8 to $11 \mathrm{~cm}$ and 15 to $11.5 \mathrm{~cm}$ at $6 \mathrm{~d}$ and $8 \mathrm{~d}$ of $70 \%$ ET in PI598453, but decreased from 12.9 to $10.8 \mathrm{~cm}, 14.9$ to $11.4 \mathrm{~cm}$, and 16 to $12 \mathrm{~cm}$ at 4,6 , and $8 \mathrm{~d}$ of $70 \%$ ET in PI403847. At 3 and $6 \mathrm{~d}$ of rewatering, HT under $70 \%$ ET was still lower than that of $100 \%$ ET for both accessions (Fig. 3). Similarly, compared with the control under $100 \% \mathrm{ET}, \mathrm{LL}$ and LW under $70 \%$ ET remained unchanged for both accessions after the first and second cuts but was significantly reduced at 6 or $8 \mathrm{~d}$ after the third cut (Fig. 4). LL decreased from 8.9 to $6.4 \mathrm{~cm}$ for PI598453 and from 9.0 to $6.5 \mathrm{~cm}$ for PI403847 at $8 \mathrm{~d}$ after the third cut, whereas LW decreased from 2.5 to $2.2 \mathrm{~mm}$ at $8 \mathrm{~d}$ for PI 598453 and from 2.8 to $2.4 \mathrm{~mm}$ and 3.0 to $2.4 \mathrm{~mm}$ at 6 and $8 \mathrm{~d}$ for PI403847. There were still $22.3 \%$ and $21.9 \%$ reductions in LL in PI403847 and $17.7 \%$ and $19.0 \%$ reductions in PI598453 after 3 and $6 \mathrm{~d}$ of recovery, but LW was fully recovered to the control level after rewatering for both accessions (Fig. 4).

After the third cut at $21 \mathrm{~d}$ of treatment, LRWC significantly decreased (Fig. 1). This could influence plant growth, as demonstrated by declines in HT, LL, and LW.
Relatively higher LRWC and SRWC in PI598453 indicates that maintenance of leaf water content contributes to better drought tolerance and lower reductions in plant growth of perennial ryegrass under DI conditions.

Gene expression. The transcript levels of HSC70 generally decreased in leaves and stems during $70 \%$ ET treatment, but were higher after rewatering in both accessions (Fig. 5). One exception was low expression of HSC 70 under $100 \%$ ET and a stronger expression under $70 \% \mathrm{ET}$ in the leaves of PI403847. Heat shock proteins (HSPs), acting as molecular chaperones, assist in a balance of protein folding, assembly, and degradation under stress conditions. Some HSP70s are also expressed in unstressed plants, known as HSC70 (heat shock cognate), indicating that they play an essential role in the maintenance of normal cell functions (Storozhenko et al., 1996). Arabidopsis (A. thaliana) plants overexpressing HSC 70-1 are compromised in dark-, $\mathrm{CO}_{2-}^{-}$, and abscisic acid-induced stomatal closure (Clément et al., 2011). High transcript levels of HSP70 were observed in drought-stressed Erianthus arundinaceus, a drought-tolerant wild relative of sugarcane (Augustine et al., 2015). The results suggested that HSC70-1

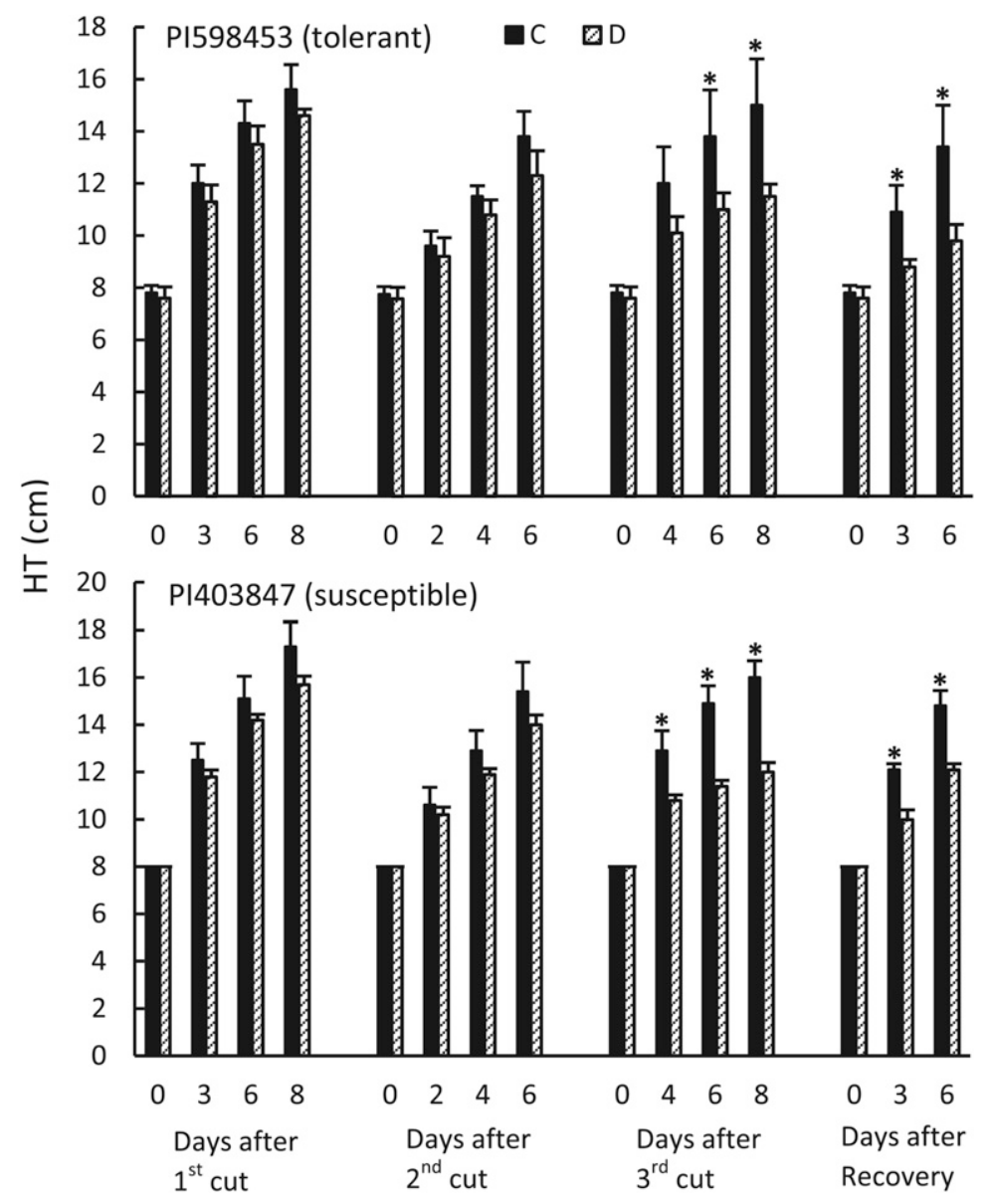

Fig. 3. Plant height (HT) as affected by irrigation at $100 \%$ evapotranspiration (ET) replacement as the control (C) and 70\% ET replacement (D) and recovery after rewatering of contrasting drought tolerant perennial ryegrass accessions. *Differences between the treatments for a given date are significant at $P<0.05$. Days after first, second, and third cut indicate the days after plants were mowed during treatments, respectively. 

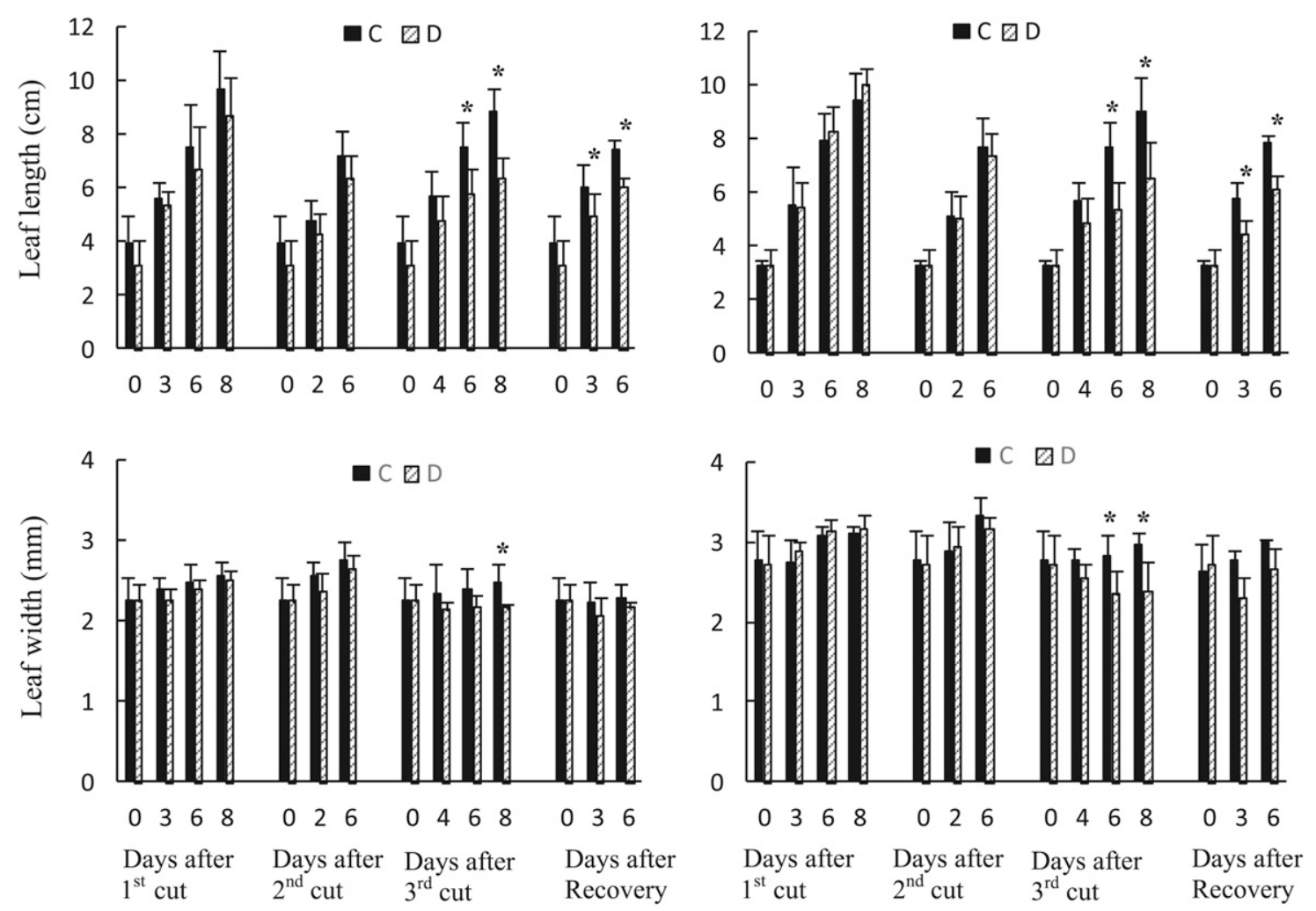

PI598453 (tolerant)

PI403847 (susceptible)

Fig. 4. Leaf length and width as affected by irrigation at $100 \%$ evapotranspiration (ET) replacement as the control (C) and $70 \%$ ET replacement (D) and recovery after rewatering of contrasting drought-tolerant perennial ryegrass accessions. *Differences between the treatments for a given date are significant at $P<0.05$. Days after first, second, and third cut indicate the days after plants were mowed during treatments, respectively.

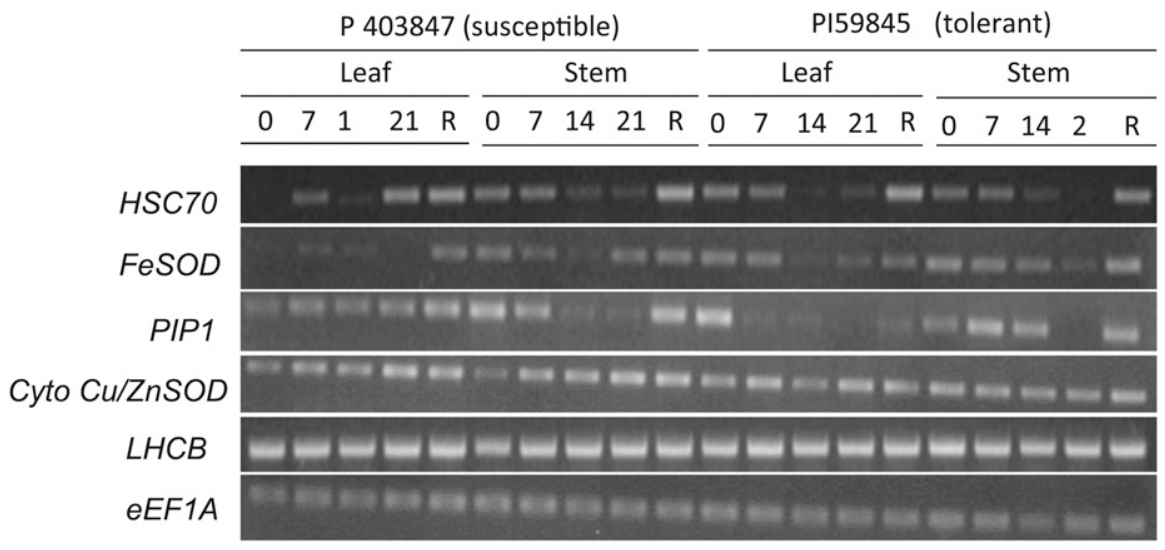

Fig. 5. Gene expressions of heat shock cognate (HSC 70), ion superoxide dismutase (FeSOD), plasma membrane intrinsic proteins type 1 (PIPI), cytosolic copper/zinc superoxide dismutase (cyto $\mathrm{Cu} / \mathrm{Zn}$ $S O D)$, and light-harvesting $\mathrm{Chl}$ a/b-binding proteins $(L H C B)$ in the leaves and stems of contrasting drought-tolerant perennial ryegrass accessions exposed to different dates of deficit irrigation (DI) at $70 \%$ evapotranspiration replacement. $0,7,14$, and 21 indicate days after DI treatment. $\mathrm{R}$ indicates recovery. $e E F 1 A$ is the internal loading control.

serves essential functions in plants to integrate signals from their abiotic environments.

Expression of $F e S O D$ was weak or remained unchanged in the leaves of PI403847 but was downregulated in the stem of PI403847 as well as in the leaves and stems in PI598453 (Fig. 5). On recovery, its expression increased back to its pre- $70 \%$ ET level. There were slightly increased expressions of cyto $\mathrm{Cu} / \mathrm{Zn} \mathrm{SOD}$ in both leaves and stems of PI 403847 in response to 70\% ET, particularly at $21 \mathrm{~d}$ of treatment (Fig. 5). But such changes were not observed in PI598453. A strong expression of cyto $\mathrm{Cu} / \mathrm{Zn}$ SOD also occurred after $7 \mathrm{~d}$ of recovery in PI403847, and a similar trend was observed in PI598453 after recovery. No changes in expression of $L H C B$ were found regardless of treatments, tissues, and accessions (Fig. 5).

SOD is among the most important enzymes in the antioxidative enzymatic system that scavenges superoxide to hydrogen peroxide (Alscher et al., 2002). There are three types of SOD isoenzymes based on their metal cofactors: copper/zinc $(\mathrm{Cu} / \mathrm{Zn})$, manganese, and iron. Transgenic maize plants overproducing an Arabidopsis FeSOD targeted into chloroplasts had an enhanced oxidative stress tolerance (Van Breusegem et al., 1999). Prashanth et al. (2008) found that the transgenic plants of rice overexpressing cDNA encoding a cytosolic $\mathrm{Cu} / \mathrm{ZnSOD}$ from mangrove (Avicennia marina) were more tolerant to both drought and salinity. The results suggest a role of SODs in drought tolerance. In kentucky bluegrass, drought reduced expressions of $\mathrm{FeSOD}$, cyto $\mathrm{Cu} / \mathrm{Zn}$ $S O D$, and chloroplastic $C u / Z n S O D$ in the leaves but expression levels were back to the control levels after rewatering. In addition, drought stress did not alter expression levels of chloroplastic $\mathrm{Cu} / \mathrm{Zn} S O D$ in prairie junegrass, compared with the control (Jiang et al., 2010). Water deficit increased mRNA accumulation of cyto $\mathrm{Cu} / \mathrm{Zn} S O D$, whereas gene expression of manganese SOD was not significantly altered in response to DI at $30 \%$ ET replacement in perennial ryegrass (Zhang et al., 2015). In addition, no differences in cyto $\mathrm{Cu}$ / $\mathrm{Zn} S O D$ expression were found between the tolerant and sensitive cultivars under $30 \%$ ET irrigation (Zhang et al., 2015). With the extended period of treatment in this study, expressions of cyto $\mathrm{Cu} / \mathrm{Zn} S O D$ were less affected by $70 \%$ ET, compared with $\mathrm{FeSOD}$ 
in perennial ryegrass; but a relatively stable expression level of cyto $\mathrm{Cu} / \mathrm{Zn} S O D$ found in PI403847 might contribute to its better tolerance to drought.

Expressions of PIP1 in the leaves of PI403847 did not change but were downregulated in the stem during $70 \%$ ET treatment and increased on recovery in both leaves and stems (Fig. 5). For PI598453, PIP1 was highly expressed in the leaves before $70 \%$ ET but its expression disappeared after $7 \mathrm{~d}$ of treatment. However, $P I P 1$ in stems was strongly expressed at $7 \mathrm{~d}$ of $70 \% \mathrm{ET}$, decreased at $14 \mathrm{~d}$, and then disappeared at $21 \mathrm{~d}$ of $70 \%$ ET but was detected after recovery. PIPs are a type of aquaporin facilitating water transport (Mahdieh et al., 2008). Most PIPs have a high level of expression under normal conditions and their transcripts are usually downregulated upon chronic drought stress in leaves of Arabidopsis (Alexandersson et al., 2005). Expression of tobacco (Nicotiana tabacum) NtPIP1; 1 and NtPIP2; 1 was downregulated to reduce osmotic hydraulic conductance in the roots under drought stress (Mahdieh et al., 2008). These decreased expressions of PIP1 may negatively impact drought tolerance in perennial ryegrass.

In summary, LRWC significantly decreased at $21 \mathrm{~d}$ of $70 \%$ ET irrigation for both accessions, but to a greater extent in the more drought-susceptible PI403847. WUE significantly increased under $70 \%$ ET, but to a greater extent in the more tolerant PI598453, whereas reduction in LDW was found only in PI403847. Regrowth was reduced after the third cut for both species exposed to $70 \% \mathrm{ET}$, but decreases in plant length and width were found earlier in PI403847 and did not recover to the control level for both accessions. The transcript levels of HSC70, FeSOD, and PIPI in both leaves and stems were generally downregulated during $70 \%$ ET treatment with a few exceptions but recovered after rewatering. Differential growth and physiological responses of perennial ryegrass accessions to DI could be used for studying molecular mechanisms of drought tolerance in perennial ryegrass.

\section{Literature Cited}

Alexandersson, E., L. Fraysse, S. Sjövall-Larsen, S. Gustavsson, M. Fellert, M. Karlsson, U. Johanson, and P. Kjellbom. 2005. Whole gene family expression and drought stress regulation of aquaporins. Plant Mol. Biol. 59:469-484.

Alscher, R.G., N. Erturk, and L.S. Heath. 2002. Role of superoxide dismutases (SODs) in controlling oxidative stress in plants. J. Exp. Biol. 531:1331-1341.

Augustine, S.M., A.V. Cherian, D.P. Syamaladevi, and N. Subramonian. 2015. Erianthus arundinaceus HSP70 (EaHSP70) acts as a key regulator in the formation of anisotropic interdigitation in sugarcane (Saccharum spp. hybrid) in response to drought stress. Plant Cell Physiol. 56:2368-2380.

Bian, S. and Y. Jiang. 2009. Reactive oxygen species, antioxidant enzyme activities and gene expression patterns in leaves and roots of
Kentucky bluegrass in response to drought stress and recovery. Sci. Hort. 120:264-270.

Bowler, C., M.V. Montagu, and D. Inze. 1992. Superoxide dismutase and stress tolerance. Annu. Rev. Plant Physiol. Plant Mol. Biol. 43:83-116.

Clément, M., N. Leonhardt, M.-J. Droillard, I. Reiter, J.-L. Montillet, B. Genty, C. Laurière, L. Nussaume, and L.D. Noël. 2011. The cytosolic/nuclear HSC70 and HSP90 molecular chaperones are important for stomatal closure and modulate abscisic acid-dependent physiological responses in Arabidopsis. Plant Physiol. 156:1481-1492.

DaCosta, M. and B. Huang. 2006. Deficit irrigation effects on water use characteristics of bentgrass species. Crop Sci. 46:1779-1786.

Ebdon, J.S. and K.L. Kopp. 2004. Relationships between water use efficiency, carbon isotope discrimination, and turf performance in genotypes of Kentucky bluegrass during drought Crop Sci. 44:1754-1762.

Eltayeb, A., N. Kawano, G. Badawi, H. Kaminaka, T. Sanekata, T. Shibahara, S. Inanaga, and K. Tanaka. 2007. Overexpression of monodehydroascorbate reductase in transgenic tobacco confers enhanced tolerance to ozone, salt and polyethylene glycol stresses. Planta 225:12551264.

Fu, J. and P.H. Dernoeden. 2008. Carbohydrate metabolism in creeping bentgrass as influenced by two summer irrigation practices. J. Amer. Soc. Hort. Sci. 133:678-683.

Fu, J. and P.H. Dernoeden. 2009. Creeping bentgrass putting green turf responses to two irrigation practices: Quality, chlorophyll, canopy temperature, and thatch-mat. Crop Sci. 49:1071-1078.

Fu, J., J. Fry, and B. Huang. 2004. Comparing three turfgrasses for minimum irrigation requirements, drought resistance and longterm performance. HortScience 39:17401744 .

Fu, J., J. Fry, and B. Huang. 2007. Tall fescue rooting as affected by deficit irrigation. HortScience 42:688-691.

Garrot, D.J. and C.F. Mancino. 1994. Consumptive water use of three intensively managed bermudagrasses growing under arid conditions. Crop Sci. 34:215-221.

Jiang, Y., E. Watkins, S. Liu, X. Yu, and N. Luo 2010. Antioxidative responses and candidate gene expression in prairie junegrass under drought stress. J. Amer. Soc. Hort. Sci. 135:303-309.

Jordan, J., R. White, D. Vietor, T. Hale, J. Thomas, and M. Engelke. 2003. Effect of irrigation frequency on turf quality, shoot density, and root length density of five bentgrass cultivars. Crop Sci. 43:282-287.

Li, J., L. Ban, H. Wen, Z. Wang, N. Dzyubenko, V. Chapurin, H. Gao, and X. Wang. 2015. An aquaporin protein is associated with drought stress tolerance. Biochem. Biophys. Res. Commun. 459:208-213.

Lian, H.-L., X. Yu, Q. Ye, X.-S. Ding, Y. Kitagawa, S.-S. Kwak, W.-A. Su, and Z.-C. Tang. 2004. The role of aquaporin RWC3 in drought avoidance in rice. Plant Cell Physiol. 45:481-489.

Liu, S. and Y. Jiang. 2010. Identification of differentially expressed genes in perennial ryegrass under drought stress. Physiol. Plant. 139:375-387.

Luo, N., J. Liu, X. Yu, and Y. Jiang. 2011. Natural variation of drought response in Brachypodium distachyon. Physiol. Plant. 141:19-29.

Mahdieh, M., A. Mostajeran, T. Horie, and M. Katsuhara. 2008. Drought stress alters water relations and expression of PIP-type aquaporin genes in Nicotiana tabacum plants. Plant Cell Physiol. 49:801-813.

Matin, M.A., J.H. Brown, and H. Ferguson. 1989. Leaf water potential, relative water content, and diffusive resistance as screening techniques for drought resistance in barley. Agron. J. 81:100-105.

Meyer, J.L. and V.A. Gibeault. 1987. Turfgrass performance when underirrigated. Applied Agr. Res. 2:117-119.

Prashanth, S.R., V. Sadhasivam, and A. Parida. 2008. Over expression of cytosolic copper/zinc superoxide dismutase from a mangrove plant Avicennia marina in indica Rice var Pusa Basmati-1 confers abiotic stress tolerance. Transgenic Res. 17:281-291.

Sass, J.F. and B.P. Horgan. 2006. Irrigation scheduling on sand-based creeping bentgrass: Evaluating evapotranspiration estimation, capacitance sensors, and deficit irrigation in the Upper Midwest. Appl. Turfgrass Sci. doi:10.1094/ ATS-2006-0330-01-RS.

Storozhenko, S., P. De Pauw, S. Kushnir, M. van Montagu, and D. Inze. 1996. Identification of an Arabidopsis thaliana cDNA encoding a HSP70related protein belonging to the HSP110/SSE1 subfamily. FEBS Lett. 390:113-118.

Turner, L.R., M.M. Holloway-Phillips, R.P. Rawnsley, D.J. Donaghy, and K.G. Pembleton. 2012. The morphological and physiological responses of perennial ryegrass (Lolium perenne L.), cocksfoot (Dactylis glomerata L.) and tall fescue (Festuca arundinacea Schreb. syn. Schedonorus phoenix Scop.) to variable water availability. Grass Forage Sci. 67:507-518.

Van Breusegem, F., L. Slooten, J. Stassart, T. Moens, J. Botterman, M. Van Montagu, and D. Inzé. 1999. Overproduction of Arabidopsis thaliana FeSOD confers oxidative stress tolerance to transgenic maize. Plant Cell Physiol. 40:515-523.

Wang, F., Q. Wang, S. Kwon, S. Kwak, and W. Su. 2005. Enhanced drought tolerance of transgenic rice plants expressing a pea manganese superoxide dismutase. J. Plant Physiol. 162: 465-472.

Xu, L., L. Han, and B. Huang. 2011. Antioxidant enzyme activities and gene expression patterns in leaves of Kentucky bluegrass in response to drought and post-drought recovery. J. Amer. Soc. Hort. Sci. 136:247-255.

Xu, Y., W. Hu, J. Liu, J. Zhang, C. Jia, H. Miao, B. $\mathrm{Xu}$, and $\mathrm{Z}$. Jin. 2014. A banana aquaporin gene, MaPIP $1 ; 1$, is involved in tolerance to drought and salt stresses. BMC Plant Biol. 14:59.

Xu, C., M. Wang, L. Zhou, T. Quan, and G. Xia. 2013. Heterologous expression of the wheat aquaporin gene TaTIP2;2 compromises the abiotic stress tolerance of Arabidopsis thaliana. PLoS One 8:e79618.

Yu, X., G. Bai, S. Liu, N. Luo, Y. Wang, D.S. Richmond, P.M. Pijut, S.A. Jackson, J. Yu, and Y. Jiang. 2013. Association of candidate genes with drought tolerance traits in diverse perennial ryegrass accessions. J. Expt. Bot. 64:1537-1551.

Zhang, X., E.H. Ervin, Y. Liu, G. Hu, C. Shang, T. Fukao, and J. Alpuerto. 2015. Differential responses of antioxidants, abscisic acid, and auxin to deficit irrigation in two perennial ryegrass cultivars contrasting in drought tolerance. J. Amer. Soc. Hort. Sci. 140:562-572.

Zhou, P., Y. An, Z. Wang, H. Du, and B. Huang. 2014. Characterization of gene expression associated with drought avoidance and tolerance traits in a perennial grass species. PLoS One 9: e103611. 